\title{
The physiological evaluation of sports activities of basketball players
}

\author{
V.M. Koryahin, O.Z. Blavt \\ Lviv Polytechnic National University, Ukraine; e-mail: oksanablavt@ukr.net
}

\begin{abstract}
The purpose of the study was to assess the activity of basketball players (participants in international tournaments) during competitions and in the training process by establishing changes in physiological functions. According to the assessment of the physiological features of basketball players activities during the competitions, changes in the players' physiological functions during training and competitions have been found out. It has been established that physiological changes in basketball players'bodies depend on the nature of the play activity and the protection system. The level of oxygen consumption during the game varies from 72.3 to $96.6 \%$ of the maximum oxygen consumption with an average of $85.8 \%$. According to the results of the experiment it became clear that the functions of various organs and systems of basketball players develop during the competitions. Therefore, it is necessary to pay great attention to development of both aerobic and anaerobic qualities of athletes in the course of training, in particular of anaerobic glycolytic the speed endurance depends on. The change of protection systems during the game significantly influences aerobic and anaerobic metabolism indicators. The presented empirical results of the research carried out allow us to conclude that the energy supply of sports competitions in basketball is aerobicanaerobic in nature with high proportion of glycolysis. In general, physiological changes in basketball players'bodies depend on the nature of the play activity and the protection system.

Keywords: basketball; competitive activities; training; physiological changes.
\end{abstract}

\section{INTRODUCTION}

Basketball is an athletic game that sets high requirements for sportsmen's mobile and functional abilities. Participation in the game requires the athlete to maximize the mobilization of his physical and functional abilities. Functional preparedness of athletes is a complex and dynamic process based on the deep understanding of factors that determine its effectiveness. It is related to the fact that physiological processes cause manifestation of all motor qualities, ensure execution of the technical techniques as well as tactical thinking of an athlete [1].

The functional training of basketball players in modern basketball is of particular importance in connection with the expansion of the range of their game activities, the increase in the intensity of the game, which requires sportsmen to exert maximum muscular efforts in a situation that is rapidly changing on the site.
In order to effectively increase the physical capacity of sportsmen, in particular basketball players, it is necessary to know: what requirements the game itself sets for individual functions of the body and physical qualities of basketball players, how big these requirements are, what physical possibilities of the basketball players are, to which physical and functional qualities it is necessary first of all to pay attention in the process of training, which means and methods of training are most effective for the development of these or other qualities and, finally, how to build rationally the training process, that is, how to distribute effectively training means and methods at various stages of training the basketball players for competitions [2].

It is proved that effectiveness of the basketball players' training system will increase significantly if it is conducted by taking into account the scientifically grounded strategy of the 
physiological function development as well as those processes that occur in organs and systems of their bodies under the influence of the training and competitive activities. However, the point of functional state indicators and preparedness of athletes is constantly under scientific research [3-5], the issue of setting criteria for individual functions and physical qualities of basketball players and physical loading during the game still needs research.

The purpose of the study was to assess the activity of basketball players (participants in international tournaments) during competitions and in the training process by establishing changes in physiological functions.

\section{METHODS}

We strived to assess the physiological features of basketball players' activities during the competitions and find out changes in the players' physiological functions during training and competitions. We examined highly qualified athletes - international tournaments participants. The players' activity among men's teams was evaluated using timing. The duration of the active and passive phases of the game was recorded. The active phase - from the moment the player touches the ball on the site and until the ball has gone out of bounds, and the passive phase - since stopping the stopwatch which counted the period of the active phase until the ball is returned into the game. At the same time, the content of these phases and reasons for stopping the game have been analyzed. The games were timed during the experiment.

The volume of shifts in the bodies of basketball players was being detected in various ways. The study of the heart rate during competitions was conducted by means of the method of continuous automatic registration using the multichannel system [6]. This allowed determine the maximum mean pulse rate during the game, as well as the maximum pulse rate total during the game and during the recovery.

The level of pulmonary ventilation was de- termined by way of collecting expired air into Douglas bags with the subsequent measurement of the volume of the air contained in the bag using a laboratory gas meter. The accuracy of the gas meter readings was checked by passing a precisely measured volume of air through it. When passing 100 litres of control volume of air, the deviation in the gas meter readings in 35 measurements amounted to an average of $0.84 \pm 0.13$.

The air collection was carried out using a breathing mask and a low-resistance valve $(6 \mathrm{~mm}$ $\mathrm{Hg})$ at the air flow velocity of $3001 / \mathrm{min}$. The diameter of the air-conducting paths was $4.5 \mathrm{~cm}$.

In competitive games, the level of the pulmonary ventilation was determined during the replacement of the players, as well as during the game breaks. All parameters of ventilation of lungs were brought to the conditions of the body temperature, atmospheric pressure and saturation with water vapour.

The percent composition was determined by way of analyzing the samples using the gas analyzers Spirolit and ME-TAMAX that are capable of recording the concentration of $\mathrm{O}_{2}$ and $\mathrm{CO}_{2}$ in expired air. The accuracy of the performed analyzes was controlled using duplicate determinations of the gas composition of the same sample. The total error in the measurements of $\mathrm{O}_{2}$ consumption and $\mathrm{CO}_{2}$ release during competitive activity made up $0.9 \%$.

In the recovery period, air samples were taken for 32 minutes. At the same time, the sportsmen's heart rate was also recorded during the recovery period. All the indicators of the heart rate, as well as the level of $\mathrm{O}_{2}$ consumption, total $\mathrm{O}_{2}$, the level of $\mathrm{CO}_{2}$ release and oxygen pulse rate were calculated according to the method described in the works $[3,7]$. The results of the game timing during the national championship and in international basketball tournaments are shown in Table 1.

\section{RESULTS AND DISCUSSIONS}

Consequently, basketball players are in very tense condition during the game for quite a long 
time. According to our observations, the game lasts for $69 \mathrm{~min} 27.7 \mathrm{~s}$ on average, not taking the breaks between the two halves into account. Other authors recorded values close to our results (65 min $53.6 \mathrm{sec}$ ) [8-11]. Average duration of the first half is $34 \mathrm{~min} 20.6 \mathrm{~s}$, of the second half $-35 \min 7.1 \mathrm{~s}$.

The active phase lasts on average for $27.7 \mathrm{~s}$. The periods of active activity are repeated after every $20.4 \mathrm{~s}$ of the passive phase. In the course of the game with ball running out, with technical errors, playing out a jump ball, personal remarks, for which foul shot are not assigned, the passive phase lasts, as a rule, 2-10 s. Provided minute breaks, performance of foul shots and replacements its duration increases to $0.5-2.5 \mathrm{~min}$.

As for the indices of the average number of active and passive phases of the game, certain differences have been identified $(\mathrm{P}<0.01)$. The same applies to average duration of the active and passive phases of the game between the first and second parts. Longer duration of the passive phase in the second half, apparently, is partly due to the fact that as a result of athletes' increased fatigue $35.7 \%$ of the fouls received by the team are hit here, and only $25.7 \%$ in the first half of the game.

The time structure of the game somehow indicates the nature of the energy supply of basketball players during the work. During the gaming activity period lasting for about $30 \mathrm{~s}$, the aerobic process fails to reach its maximum power, while the anaerobic one is meanwhile being exhausted in the working muscles $[12,13]$. The most important role in the energy supply of the exercise at such time intervals is played by anaerobic glycolytic process [14,5]. However, since active pauses with significant reference to glycolysis are multiply repeated (89 times per game) through relatively short (20 s) rest intervals, then during the game the conditions for aerobic process reference are also created. It may be assumed that the energy supply of basketball players during the game will have a mixed aerobic-anaerobic character with high specific gravity of glycolytic reactions.

The direct answer to the question of which functions are most often used in the course of game can only be obtained by direct recording of the volume and nature of physiological changes in the bodies of basketball players during the matches (Table 2).

It has been found out that basketball players spend a lot of energy during the game. The level of oxygen consumption during the game varies from 72.3 to $96.6 \%$ of the maximum oxygen consumption with an average value of $85.8 \%$.

Significant activation of aerobic changes in the exercised muscles is evidenced by high level $(2.51 \mathrm{l} / \mathrm{min} / \mathrm{kg})$ of alactic $\mathrm{O}_{2}$-consumption. Indicators of lactic $\mathrm{O} 2$ consumption are also

Table 1. Results of the games timing in international basketball tournaments $(n=50)$

\begin{tabular}{lcccc}
\hline \multicolumn{1}{c}{ Indices } & First half & Second half & Total for the game \\
\hline Total number of active & $45.5^{1} \pm 1.25^{2}$, & $43.5 \pm 1.34 ;$ & $89.0 \pm 1.34 ;$ \\
phases during the game & $6.5^{3}$ & 7.0 & 7.0 \\
Total number of passive & $44.5 \pm 1.25$, & $42.5 \pm 1.34 ;$ & $89.0 \pm 1.34 ;$ \\
phases during the game & 6.5 & 7.0 & 7.0 \\
Average duration of the active & $26.9 \pm 0.77 ;$ & $28.4 \pm 0.84 ;$ & $27.7 \pm 0.84 ;$ \\
phase of the game, sec & 4.02 & 4.37 & 4.37 \\
Average duration of the passive & $19.3 \pm 0.55 ;$ & $21,5 \pm 0,7 ;$ & $20,4 \pm 0,7 ;$ \\
phase of the game, sec & 2.87 & 3.65 & 3.65 \\
Game total duration & $34 \mathrm{~min}$ & $35 \mathrm{~min}$ & $69 \mathrm{~min}$ \\
& $20.6 \mathrm{~s}$ & $7.1 \mathrm{~s}$ & $27.7 \mathrm{~s}$ \\
Fraction of «net» playing time in the & & & 57.5 \\
total duration & 58.3 & 57.0 & 5 \\
\hline
\end{tabular}

Note: the numbers given in the table mean: ${ }^{1}$ average, ${ }^{2}$ standard error of average, ${ }^{3}$ standard deviation 
Table 2. Results of study of the training and competitive games influence on the bodies of basketball players $(\mathrm{n}=50)$

\begin{tabular}{l|c|c|}
\hline \multicolumn{1}{c|}{ Indices } & Game time & Range of variability \\
\hline Total time of participation in the game, & 18.59 & $3.5-38.16$ \\
min. & 27.98 & $4.9-68.10$ \\
Maximum heart rate during the game, bpm & 198,9 & $180-230$ \\
Average heart rate during the game, bpm & 114,0 & $90,5-147.6$ \\
Maximum pulse sum, bpm & 2346,7 & $637-4450$ \\
Maximum recovery sum, bpm & 3396.9 & $1991-4059$ \\
$\mathrm{O}_{2}$-consumption level, $1 / \mathrm{min} / \mathrm{kg}$ & 85.8 & $72.3-96.6$ \\
$\mathrm{O}_{2}$-consumption, \% from the maximal index & 3.25 & $28.7-3.78$ \\
Total O ${ }_{2}$ - debt, 1 & 5.87 & $4.49-7.9$ \\
$\mathrm{CO}_{2}$-emission level, $1 / \mathrm{min}$ & 2.9 & $2.53-3.4$ \\
Pulmonary ventilation level, $1 / \mathrm{min}$ & 79.5 & $59.5-105,1$ \\
Oxygen pulse, ml per beat & 17.0 & $15.0-19.9$ \\
\hline
\end{tabular}

${ }^{1}$ «Net» time of participation in the game in the numerator and total time of the game in the denominator.

moderately high $(0.42 \mathrm{l} / \mathrm{min} / \mathrm{kg})$, which shows the degree of myocardium metabolic activity. Significant activation of cardiac activity is confirmed by the maximum heart rate $-198.9 \mathrm{bpm}$ on average within the range from 180 to $230 \mathrm{bpm}$.

Participation in a tense game along with significant activation of aerobic functions leads to considerable use of anaerobic energy sources [3]. This, in particular, is confirmed by the value of $\mathrm{O}_{2}$-debt, which reaches 4.5-7.9 liters at the end of the game. The corresponding value of heart rate insufficiency in these conditions varies from 1991 to $4058 \mathrm{bpm}$. «Excess» of carbon dioxide reaches $1.32 \mathrm{l} / \mathrm{min}$.

The change in protection systems in the course of game is significantly reflected in the indicators of aerobic and anaerobic metabolism. Most often this is observed at the application of «pressing» protection system. Changes in physiological parameters of basketball players of different roles after 19 minutes of game are shown in Figure. The oxygen and heart rate debt of the player, who played the role of the attacker, changes the most. The level of $\mathrm{O}_{2}$-consumption did not change significantly during the game.

Interpretation of the received data about the changes in the players' physiological functions in the process of training and competition makes it possible to better understand them. The result obtained during the control of the physiological features of basketball players was consistent with the information $[9,11,15,16]$, that basketball players spend a lot of energy during the game.

The experiment analysis showed that the functions of various organs and systems of
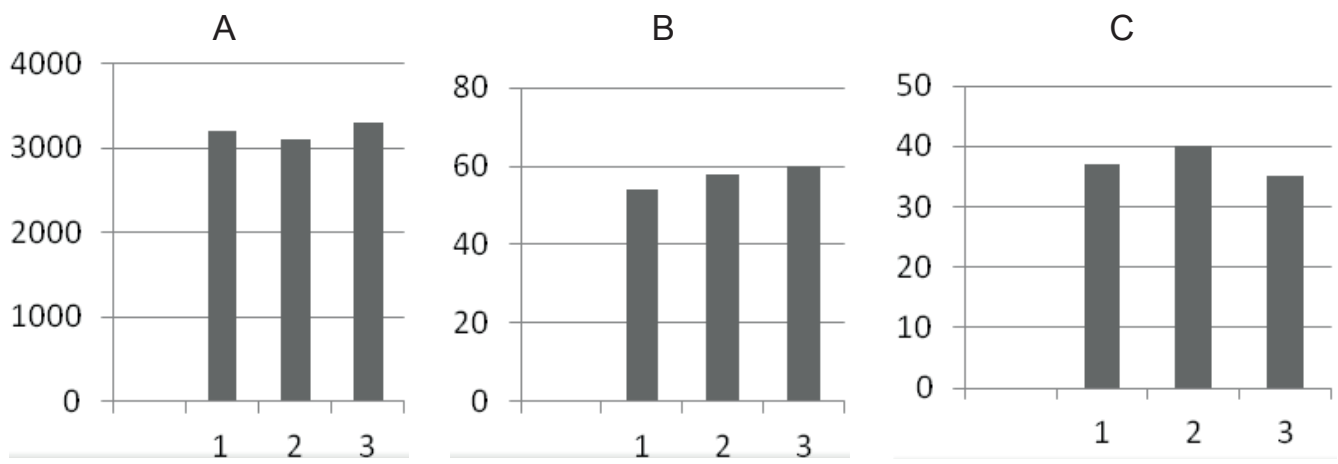

The values: of the heart rate debt / bpm (A), oxygen debt, $1 / \mathrm{min} / \mathrm{kg} /(\mathrm{B})$, the level of $\mathrm{O}_{2}$-consumption, $1 / \mathrm{min}(\mathrm{C})$ in $1^{\text {st }}$ class basketball players: 1 - data of central player; 2 - defender; 3 -attacker 
basketball players develop during the competitions. Therewith, we state it is necessary to pay great attention to development of both aerobic and anaerobic qualities of athletes in the course of training, in particular of anaerobic glycolytic the speed endurance depends on. It is as well necessary to develop aerobic capacity because the efficiency of the gaming activities implementation in oxygen supply of the body is gy processes' disturbed balance, and this property is determined by the level of development of players' aerobic capabilities. This confirms the information available in the literature [3, 5, 17-19].

We reconcile our results $[1,10,20]$ that defenders and attackers move more during the game than the center players. However, the center players are actively involved in the fight for the ball under the shield. Therefore, the load on the body of basketball players of various game functions is approximately the same players with different roles have the same requirements for functional training $[3,2,16]$.

The results of the study supplement the information on the pedagogical control of competitive and training activities of basketball players regulating the expediency of pedagogical influences to ensure the efficiency of the basketball players' competitive activities [2, 6, 15].

\section{CONCLUSIONS}

Thus, the energy supply of basketball sporting events is of aerobic-anaerobic nature with high specific gravity of glycolysis. Physiological changes in basketball players' bodies depend on the nature of the play activity and the protection system. The «pressing» system is accompanied by considerably greater strain than personal and zone protection systems.

The authors of this study confirm that the research and publication of the results were not associated with any conflicts regarding commercial or financial relations, relations with organizations and/or individuals who may have been related to the study, and interrelations of co authors of the article.

\section{В.М. Корягін, О.3 Блавт \\ ФІЗІОЛОГІЧНА ОЦІККА СПОРТИВНОЇ ДІЯЛЬНОСТІ БАСКЕТБОЛІСТІВ}

Мета дослідження полягала в оцінці діяльності баскетболістів (учасників міжнародних турнірів) під час змагань та у процесі тренування установленням змін фізіологічних функцій. За результатами педагогічної оцінки фізіологічних характеристик діяльності баскетболістів з`ясовано зміни фізіологічних функцій гравців у процесі тренування та змагань. Установлено, що фізіологічні зміни в організмі баскетболістів залежать від характеру ігрової діяльності і системи захисту. Рівень споживання кисню під час гри варіює від 72,3 до 96,6\% від максимуму із середнім значенням 85,8\%. Згідно з підсумками експерименту під час змагань розвиваються функції різних органів і систем баскетболістів. Тому в процесі тренування треба приділяти велику увагу розвиткові як аеробних, так і анаеробних якостей спортсменів, зокрема анаеробних гліколітичних від яких залежить швидкісна витривалість. Зміна в процесі гри систем захисту істотно позначається на показниках аеробного і анаеробного обміну. Представлені емпіричні результати проведеного дослідження дають змогу зробити висновок про те, що енергетичне забезпечення спортивних змагань з баскетболу носить аеробно-анаеробний характер 3 великою питомою вагою гліколізу. Загалом, фізіологічні зміни в організмі баскетболістів залежать від характеру ігрової діяльності і системи захисту.

Ключові слова: баскетбол; змагальна діяльність; тренування фізіологічні зміни.

Національний університет «Львівська політехніка»; e-mail: oksanablavt@ukr.net

\section{В.М. Корягин, О.3. Блавт}

\section{ФИЗИОЛОГИЧЕСКАЯ ОЦЕНКА СПОРТИВ- НОЙ ДЕЯТЕЛЬНОСТИ БАСКЕТБОЛИСТОВ}

Цель исследования заключалась в оценке деятельности баскетболистов (участников международных турниров) во время соревнований и в процессе тренировки путем установления изменений физиологических функций. По результатам оценки физиологических характеристик деятельности баскетболистов выяснены изменения физиологических функций игроков в процессе тренировки и соревнований. Установлено, что физиологические изменения в организме баскетболистов зависят от характера игровой деятельности и системы защиты. Уровень потребления кислорода во время игры варьирует от 72,3 до $96,6 \%$ от максимума со средним значением $85,8 \%$. Согласно итогов эксперимента установлено, что во время соревнований развиваются функции различных 
органов и систем баскетболистов. Поэтому в процессе тренировки нужно уделять большое внимание развитию как аэробных, так и анаэробных качеств спортсменов, в частности анаэробных гликолитических от которых зависит скоростная выносливость. Изменение в процессе игры систем защиты существенно отражается на показателях аэробной и анаэробной обмена. Представленные эмпирические результаты проведенного исследования позволяют сделать вывод о том, что энергетическое обеспечение спортивных соревнований в баскетболе имеет аэробно-анаэробный характер с большим удельным весом гликолиза. Установлено, что физиологические изменения в организме баскетболистов зависят от характера игровой деятельности и системы защиты.

Ключевые слова: баскетбол; соревновательная деятельность; тренировки физиологические изменения.

\section{REFERENCES:}

1. Ramos R, Rubio J, Martínez F, Esteban P, Jiménez J. Physiological, podological and somatometric characteristics of professional basketball player. Archivos de Medicina del Deporte. 2010;27(136):84-94.

2. Poplavskyi LYu. Basketball. Kyiv: Olimpiiska Literaturea; 2004. [Ukrainian].

3. Ulmor JH, Kostill DL. Physiology of sport and motor activity. Kyiv: Olimpiiska Literaturea. 2001. [Russian].

4. McArdle W, Katch F, Katch V. Exercise physiology: energy, nutrition and human performance. Lea and Fabiger. Philadelphia. London. 1991.

5. Sallet P, Perrier D, Ferret JM, Vitelli V, Baverel G. Physiological differences in professional basketball players as a function of playing position and level of play. J Sport Med Phys Fit. 2005;(45):291-5.

6. Method of multichannel monitoring of heart rate: patent 68771 Ukraine: IPC A63V69 / 00 / Koryagin V, et al. 2012. [Ukrainian].

7. Korjagin VM. Training of the highly skilled basketball players. Lviv: «Krai». 1998. [Ukrainian].

8. Bogdanovska NV, Kotsuruba AV, Malikov MV. Features of metabolism of arginine and nitric oxide synthesis in young men during adaptation to physical stress during training and competitive periods Fiziol Zh. 2011;57: 45-54. [Ukrainian].

9. Hoare DG. Predicting success in junior elite basketball players-the contribution of anthropometic and physiological attributes. J Sci Med Sport. 2000;3(4): 391-405.

10. Vuckovic I, Mekic M. Morfological characteristics of basketball players from playing position aspect. In 1st International Scientific Conference. Exercise and Quality of Life. University of Novi Sad. 2009;309-16.

11. Ben Abdelkrim N, Castagna C, El Fazaa S, El Ati J. The effect of players' standard and tactical strategy on game demands in men's basketball. J Strength Cond Res. 2010;24:2652-62.

12. Korobeynikova LG, Makarchuk MYu, Korobeynikov GV, Mischenko VS, Zapovitryana OB. States of psychophysiological functions of elite athletes in different aging groups Fiziol. Zh. 2016;62(6):81-7. [Ukrainian].

13. Keul G, Doll E, Keppler D. Muskelstoffvechsel. Stellenwert der Sportmedizin in Medizin und Sportwissenschaft. Munchen. 1969.

14. Taylor HL, Buskirk E, Henschel A. Maximal oxygen intake as an objective measure of cardio-respiratory performance. J Appl Physiol. 1955;8:73-80.

15. Vinnichuck JuD, Gunina LM. Vascular endothelial growth factor during physical loads with different mechanism of energy's providing of muscular work. Fiziol. Zh. 2015;61(1):63-71.

16. Sampaio J. Effects of season period, team quality, and playing time on basketball players' game-related statistics. Europ J Sport Sci. 2010;10(2):141-9.

17. Crisafulli A, Melis F, Tocco F, et al. Anaerobic threshold and the oxygen consumption-cardiac output relationship during exercise. Sport Sci Health. 2005;1(2):75-80.

18. Ben Abdelkrim N, El Fazaa S, El Ati J. Time-motion analysis and physiological data of elite under-19-yearold basketball players during competition. Br J Sports Med. 2007;41:69-75.

19. Chernozub AA. The security and critical levels of physical activity for trained and untrained persons in muscle performance power orientation. Fiziol Zh. 2016;62(2):1106. [Ukrainian].

20. Koryagin V, Blavt O, Grebinca G. Optimization of the technical training system. J Phys Ed Sport. 2016; 16(2):1029-30. 